\title{
Performans Ayam Ketarras Pada Umur 12 Minggu Sampai Dewasa Kelamin Berdasarkan Pola Warna Bulu
}

\section{Performance of Ketarras Chicken in 12 Weeks of Age through Sexually Mature Based on Feather Color Pattern}

\author{
H. T. Murdiono, D. Kaharuddin, dan Kususiyah \\ Jurusan Peternakan, Fakultas Pertanian, Universitas Bengkulu \\ Jalan Raya W. R. Supratman, Kandang Limun, Bengkulu, 38371 A \\ Corresponding email : heru.trimurdiono60@gmail.com
}

\begin{abstract}
This study aimed to evaluate the performance of Ketarras chicken at 12 weeks of age to matured sex based on feather color patterns. The research was conducted at the cage of the Commercial Zone and Animal Laboratory (CZAL) Department of Animal Husbandry, Faculty of Agriculture, University of Bengkulu. This study used a completely randomized design with 3 treatments of 20 replications. The treatments were the color pattern of feathers with P1 = dark feather color pattern, $\mathrm{P} 2=$ white blurik feather pattern and P3 = white feather color pattern. Each replication uses 1 chicken, so that each feather color pattern requires 20 chickens that are placed randomly on individual battery cages. Variables observed were ration consumption, initial body weight, weekly body weight, weekly weight gain, ration conversion, sex adult age, first egg weight and genital adult weight. The results of the analysis showed that differences in feather color patterns had no significant effect $(\mathrm{P}>0.05)$ on the observed variables. Cumulative ration consumption for the ages of 12-18 weeks P1 (2581.45 g / head), P2 (2581.20 g / head) and P3 (2622.80 g / head). Achievement of body weight at 18 weeks at P1 (940.85 g / head), P2 (908.95 g / head) and P3 (901.95) with weight gain P1 (296.75 g / head), P2 (305, $30 \mathrm{~g} /$ head) and P3 (315.70 g / head). Cumulative ration conversion P1 (8.70), P2 (8.45) and P3 (9,31). Adult sex age P1 (145 days), P2 (142 days) and P3 (148 days). Adult sex weight P1 (1035 g / head), P2 (992 g / head) and P3 (1015 g / head). Egg weight P1 (32 g / grain), P2 (31 g / item) and P3 (31 g/ item). This study concluded that differences in qualitative properties (feather color patterns) did not affect the performance of Chicken Rice aged 12 weeks to sexual maturity.
\end{abstract}

Key words: performance, growth, chicken Ketarras

\begin{abstract}
ABSTRAK
Penelitian ini bertujuan untuk mengevaluasi performans ayam Ketarras pada umur 12 minggu sampai dewasa kelamin berdasarkan pola warna bulu. Penelitian dilaksanakan di kandang Comercial Zone and Animal Laboratory (CZAL) Jurusan Peternakan Fakultas Pertanian Universitas Bengkulu. Penelitian ini menggunakan rancangan acak lengkap dengan 3 perlakuan 20 ulangan. Perlakuan yang dicobakan adalah pola warna bulu dengan P1 = Pola warna bulu gelap, P2 = pola warna bulu putih blurik dan P3 = pola warna bulu putih. Setiap ulangan menggunakan 1 ekor ayam, sehingga masing-masing pola warna bulu dibutuhkan 20 ekor ayam yang ditempatkan secara acak pada kandang batteray individu. Variabel yang diamati adalah konsumsi ransum, berat badan awal, berat badan mingguan, pertambahan berat badan mingguan, konversi ransum, umur dewasa kelamin, berat telur pertama dan berat dewasa kelamin. Hasil analisis menunjukkan bahwa perbedaan pola warna bulu berpengaruh tidak nyata $(\mathrm{P}>0,05)$ terhadap variabel yang diamati. Konsumsi ransum kumulatif selama umur 12-18 minggu P1 (2581,45 g/ekor), P2 (2581,20 g/ekor) dan P3 (2622,80 g/ekor). Capaian berat badan umur 18 minggu pada P1 (940,85 g/ekor), P2 (908,95 g/ekor) dan P3 $(901,95)$ dengan pertambahan berat badan P1 (296,75 g/ekor), P2 (305,30 g/ekor) dan P3 (315,70 g/ekor). Konversi ransum kumulatif P1 (8,70), P2 $(8,45)$ dan P3 $(9,31)$. Umur dewasa kelamin P1 (145 hari), P2 (142 hari) dan P3 (148 hari). Berat dewasa kelamin P1 (1035 g/ekor), P2 (992 g/ekor) dan P3 (1015 g/ekor). Berat telur bertama P1 (32 g/butir), P2 (31 $\mathrm{g} /$ butir) dan P3 (31 g/butir). Penelitian ini disimpulkan bahwa perbedaan sifat kualitatif (pola warna bulu) tidak mempengaruhi performans Ayam Ketarras umur 12 minggu sampai dewasa kelamin.
\end{abstract}

Kata kunci: performans, pertumbuhan, ayam Ketarras 


\section{PENDAHULUAN}

Permintaan telur ayam Kampung yang selalu meningkat dipenuhi peternak dengan memelihara ayam Arab, mengingat ukuran dan bentuk telurnya menyerupai telur ayam kampung. Namun demikian konsumen yang mengetahui dan paham dengan telur ayam kampung tidak bisa menerimanya, karena warna kerabang telur ayam Kampung adalah putih kecoklatan, sedangkan warna kerabang telur ayam Arab putih. Untuk mengatasi hal di atas telah dilakukan persilangan antara ayam Arab dengan ayam Ras petelur coklat dengan harapan muncul kerjasama (komplementer antara warna kerabang telur ayam Ras dan kerabang telur ayam Arab sehingga dihasilkan telur berwarna putih kecoklatan dan produktifitas yang tinggi). Persilangan ayam Arab jantan dengan ayam Ras betina menghasilkan ayam yang diberi nama Arras (Anggriawan, 2016). Ambarwati (2016) melaporkan telur ayam Arras masih dominan menyerupai telur ayam Ras dilihat dari ukuran dan warnanya.

Persilangan antara ayam Arras betina dengan ayam Arab dilakukan untuk mengurangi warna coklat pada kerabang telur karena dengan menambahkan genetik ayam Arab diharapkan warna kerabang telur akan menyerupai telur ayam Kampung. Hasil persilangan ayam Arras betina dengan ayam Arab jantan diberi nama Ketarras (keturunan Arab dan Arras). Hasil penelitian Saputra (2018) menyatakan rataan ukuran berat telur ayam Ketarras 46,70 gram, Surnoto (2018) menyatakan warna telur ayam Ketarras 90,96 $\%$ berwarna putih kecoklatan. Marliya (2017) melaporkan bahwa akseptabilitas konsumen terhadap telur ayam Ketarras sebagai telur ayam Kampung 86,21\%. Lebih lanjut Marliya (2017) menyatakan, telur ayam Ketarras sudah bisa diterima dan dihargai sama dengan telur ayam Kampung.

Selain warna kerabang, sifat kualitatif yang juga menarik dipelajari adalah warna bulunya. Ayam persilangan ayam Arab dan ayam Ras petelur ini telah memunculkan warna berbeda dari tetuanya, diantaranya warna hitam, coklat, bercak hitam dan warna putih polos. Secara garis besar bisa dikelompokkan menjadi 3 kelompok yaitu warna gelap, putih blurik dan putih. Hal ini belum diungkap apakah warna bulu ada pengaruhnya terhadap performans ayam Ketarras. Telah dilakukan penelitian pola warna bulu ayam Ketarras terhadap pertumbuhan. Penelitian ini menunjukkan bahwa pola warna bulu tidak mempengaruhi performans pertumbuhan ayam Ketarras (Hidayatullah, 2018) maka penelitian ini dilakukan untuk melihat performans selanjutnya apakah benar sifat kualitatif tidak berpengaruh terhadap produksi ayam Ketarras.

Fase pemeliharan ayam Petelur dibagi beberapa fase, yaitu fase starter, grower dan layer. Penelitian ini menggunakan ayam Ketarras fase grower dan dirancang untuk melihat pengaruh pola warna bulu terhadap performas ayam Ketarras umur 12 minggu sampai dewasa kelamin. Penelitian ini bertujuan untuk mengevaluasi performans ayam Ketarras sejak umur 12 minggu sampai dewasa kelamin berdasarkan pola warna bulu. Diduga performans ayam Ketarras sejak umur 12 minggu sampai dewasa kelamin dengan pola warna bulu berbeda adalah tidak berbeda.

\section{MATERI DAN METODE}

Penelitian ini merupakan penelitian lanjutan dari penelitian sebelumnya yang berjudul "Performans Ayam Ketarras pada umur 2 sampai 12 minggu berdasarkan pola warna bulu", sedangkan penelitian ini berjudul "Performans ayam Ketarras pada umur 12 minggu sampai dewasa kelamin berdasarkan pola warna bulu". Penelitian dilaksanakan selama tiga bulan di Kandang Comercial Zone, Jurusan Peternakan, Fakultas Pertanian Universitas Bengkulu. Peralatan yang digunakan pada penelitian ini adalah kandang batteray individu, ember, timbangan, sapu, desinfektan, tempat pakan, dan tempat minum ayam. Bahan yang digunakan dalam penelitian ini yaitu Ayam Ketarras umur 12 minggu, serta bahan pakan 
yang terdiri dari dedak, jagung giling dan KLK (konsentrat layer khusus).

\section{Pemeliharaan Ayam Umur 12 Minggu - Dewasa Kelamin}

Kandang yang digunakan adalah kandang batteray individu sebanyak 60 petak, setiap petak berukuran panjang $50 \mathrm{~cm}$, lebar $23 \mathrm{~cm}$ dan tinggi $50 \mathrm{~cm}$. Kandang dilengkapi dengan tempat pakan dan tempat minum. Penelitian dilakukan selama 2,5 bulan, menggunakan ayam Ketarras umur 12 minggu sebanyak 60 ekor dengan tiga jenis warna bulu yang dipelihara dalam kandang batteray individu.

Ransum yang diberikan selama umur 12-18 minggu adalah ransum petelur dengan kandungan protein sebesar $15 \%$ dan energi metabolik sebesar 2900 (kkal/kg) (NRC, 1994). Setelah berumur 18 minggu protein pakan dinaikkan dari $15 \%$ menjadi $17 \%$.
Ransum diberikan dua kali sehari yaitu pada pagi hari pukul 07.00 dan sore hari pukul 16.00 WIB. Ransum diberikan sesuai jumlah dan konsumsi yang terdapat pada Tabel 4 . ditambah $10 \%$ sebagai cadangan pakan. Air minum diberikan ad libitum. Pemberian ransum diberikan setiap hari sesuai dengan kebutuhan ayam, baik secara kuantitatif maupun kualitatif (Fadilah, 2004). Setiap seminggu sekali ayam ditimbang untuk mengetahui berat badan. Bahan penyusun ransum yang digunakan dalam penelitian ini adalah dedak halus, jagung giling, dan KLK (Konsentrat Layer Khusus). Kandungan nutrisi bahan penyusun ransum, formulasi ransum penelitian dan kandungan nutrisi ransum umur 12 minggu - dewasa kelamin serta pemberian konsumsi ransum ayam petelur dapat dilihat pada Tabel 1., Tabel 2.,dan Tabel 3.

Tabel 1. Kandungan nutrisi bahan penyusun ransum

\begin{tabular}{lcccccc}
\hline Bahan Ransum & $\begin{array}{c}\text { PK } \\
(\%)\end{array}$ & $\begin{array}{c}\text { ME } \\
(\mathrm{kkal} / \mathrm{kg})\end{array}$ & $\begin{array}{c}\text { SK } \\
(\%)\end{array}$ & $\begin{array}{c}\text { Lemak } \\
(\%)\end{array}$ & $\begin{array}{c}\text { Ca } \\
(\%)\end{array}$ & $\begin{array}{c}\text { P } \\
(\%)\end{array}$ \\
\hline Dedak $^{\mathrm{a}}$ & 11,9 & 2460 & 12 & 9,78 & 0,01 & 1,3 \\
Jagung $^{\mathrm{a}}$ & 8,9 & 3321 & 2,5 & 2,97 & 0,02 & 0,23 \\
KLK $^{\mathrm{b}}$ & 33 & 2.700 & 9,83 & 6,37 & 10,87 & 1,28 \\
\hline
\end{tabular}

Keterangan a : Hartadi et al. (2005); b : Label KLK

Tabel 2. Formulasi ransum dan kandungan nutrisi ransum umur 12-18 Minggu

\begin{tabular}{lccccccc}
\hline Bahan Penyusun & $\begin{array}{c}\text { Proporsi } \\
(\%)\end{array}$ & $\begin{array}{c}\text { PK } \\
(\%)\end{array}$ & $\begin{array}{c}\text { ME } \\
(\mathrm{kkal} / \mathrm{kg})\end{array}$ & $\begin{array}{c}\text { SK } \\
(\%)\end{array}$ & $\begin{array}{c}\text { LK } \\
(\%)\end{array}$ & $\begin{array}{c}\text { Ca } \\
(\%)\end{array}$ & $\begin{array}{c}\mathrm{P} \\
(\%)\end{array}$ \\
\hline Dedak & 28 & 3,33 & 688,8 & 3,36 & 2,73 & 0,0028 & 0,36 \\
Jagung Giling & 50 & 4,45 & 1660,5 & 1,25 & 1,48 & 1,01 & 0,11 \\
KLK & 22 & 7,26 & 594 & 2,16 & 1,40 & 2,39 & 0,28 \\
\hline Total & 100 & 15,04 & 2943,3 & 6,77 & 5,61 & 2,40 & 0,75 \\
\hline
\end{tabular}

Tabel 3. Formulasi ransum dan kandungan nutrisi ransum umur 18 minggu - dewasa kelamin

\begin{tabular}{lccccccc}
\hline Bahan Penyusun & $\begin{array}{c}\text { Proporsi } \\
(\%)\end{array}$ & $\begin{array}{c}\text { PK } \\
(\%)\end{array}$ & $\begin{array}{c}\text { ME } \\
(\mathrm{kkal} / \mathrm{kg})\end{array}$ & $\begin{array}{c}\text { SK } \\
(\%)\end{array}$ & $\begin{array}{c}\text { LK } \\
(\%)\end{array}$ & $\begin{array}{c}\text { Ca } \\
(\%)\end{array}$ & $\begin{array}{c}\text { P } \\
(\%)\end{array}$ \\
\hline Dedak & 32,00 & 3,52 & 787,20 & 3,84 & 3,13 & 0,00 & 0,42 \\
Jagung Giling & 37,00 & 3,29 & 1228,77 & 0,93 & 1,10 & 0,01 & 0,09 \\
KLK & 31,00 & 10,23 & 837,00 & 2,17 & 1,97 & 3,41 & 0,40 \\
\hline Total & 100,00 & 17,04 & 2852,97 & 6,20 & 6,20 & 3,42 & 0,90 \\
\hline
\end{tabular}


Tabel 4. Pemberian konsumsi pakan ayam petelur berdasarkan umur.

\begin{tabular}{cc}
\hline $\begin{array}{c}\text { Umur } \\
(\text { minggu })\end{array}$ & $\begin{array}{c}\text { Ayam Petelur } \\
(\mathrm{g} / \text { ekor/minggu })\end{array}$ \\
\hline 12 & 400 \\
13 & 400 \\
14 & 420 \\
15 & 420 \\
16 & 430 \\
17 & 430 \\
18 & 450 \\
\hline
\end{tabular}

Sumber : (PT. Japfa Confeed, 2001)

\section{Rancangan Penelitian}

Penelitian ini terdiri dari 3 perlakuan dan 20 ulangan. Faktor warna bulu digunakan sebagai perlakuan, yaitu : $\mathrm{P} 1=$ Ayam Ketarras betina berwarna gelap, P2 = Ayam Ketarras betina berwarna putih blurik dan P3 = Ayam Ketarras betina berwarna putih. Setiap ulangan menggunakan 1 ekor ayam, sehingga masing-masing pola warna dibutuhkan 20 ekor yang ditempatkan pada kandang batteray individu. Variabel yang diamati meliputi konsumsi ransum, konversi ransum, berat badan pertambahan berat badan, umur dewasa kelamin, berat dewasa kelamin, berat telur pertama. Konsumsi ransum diketahui dengan menghitung jumlah ransum yang diberikan pada awal minggu dikurangi dengan sisa ransum pada akhir minggu. Berat badan awal diukur dengan menimbang ayam Ketarras betina umur 12 minggu. Berat badan diukur dengan menimbang ayam Ketarras seminggu sekali dimulai sejak ayam berumur 12 minggu sampai dewasa kelamin.

\section{Pertambahan Berat Badan Mingguan}

Pertambahan berat badan diukur setiap minggu dengan cara berat badan akhir minggu (berat akhir) dikurang berat badan minggu sebelumnya (berat awal).$$
\operatorname{PBB}(\mathrm{g}) \quad=\mathrm{BB}_{\mathrm{t}}(\mathrm{g})-\mathrm{BB}_{\mathrm{t}-1}(\mathrm{~g})
$$$$
\text { Keterangan : }
$$$$
\text { PBB = Pertambahan berat badan }
$$

$$
\begin{array}{ll}
\mathrm{BB}_{\mathrm{t}} & =\text { Berat badan akhir minggu } \\
\mathrm{BB}_{\mathrm{t}-1} & =\text { Berat badan minggu sebelumnya } \\
\mathrm{t} & =\text { Waktu pengukuran (satu minggu) }
\end{array}
$$

PBB kumulatif $=$ berat badan akhir penelitian - berat badan awal penelitian

\section{Konversi Ransum}

Konversi Ransum merupakan perbandingan antara jumlah ransum yang dikonsumsi dengan pertambahan berat badan.

\section{Konversi Ransum Mingguan}

$=\frac{\text { Total Konsumsi Ransum Selama } 1 \text { Minggu }}{\text { Pertambahan Berat Badan Selama } 1 \text { Minggu }}$

Konversi Ransum Kumulatif

$$
=\frac{\text { Konsumsi Kumulatif }}{\text { PBB Kumulatif }}
$$

Umur dewasa kelamin adalah umur (hari) pada saat ayam pertama kali bertelur (Ambarwati, 2016). Berat telur pertama diukur dengan menimbang telur yang dihasilkan pertama kali. Berat dewasa kelamin diperoleh berdasarkan hasil penimbangan ayam pada saat pertama kali bertelur.

\section{Analisis Data}

Data yang diperoleh dianalisis dengan menggunakan ANOVA dan jika terdapat pengaruh yang nyata $(\mathrm{P}<0,05)$ maka diuji lanjut dengan Duncan's Multiple Range Test (DMRT) untuk melihat perbedaan antar perlakuan.

\section{HASIL DAN PEMBAHASAN}

\section{Konsumsi Ransum}

Rataan konsumsi ransum kumulatif ayam Ketarras umur 12 - 18 minggu disajikan pada Tabel 5. 
Tabel 5. Rataan konsumsi ransum kumulatif ayam Ketarras

\begin{tabular}{ccccc}
\hline \multirow{2}{*}{$\begin{array}{c}\text { Umur } \\
\text { (minggu })\end{array}$} & P1 & Konsumsi Ransum & \multirow{2}{*}{ Keterangan } \\
\cline { 2 - 4 } & \multicolumn{4}{c}{ Pram/ekor } \\
$12-13$ & $410,50 \pm 16,79$ & $409,15 \pm 12,52$ & $412,50 \pm 15,23$ & $\mathrm{~ns}$ \\
$12-14$ & $840,15 \pm 29,58$ & $833,15 \pm 22,53$ & $844,35 \pm 30,96$ & $\mathrm{~ns}$ \\
$12-15$ & $1271,40 \pm 38,85$ & $1265,80 \pm 27,57$ & $1277,40 \pm 36,73$ & $\mathrm{~ns}$ \\
$12-16$ & $1714,15 \pm 50,70$ & $1698,75 \pm 41,27$ & $1724,55 \pm 38,63$ & $\mathrm{~ns}$ \\
$12-17$ & $2150,20 \pm 64,02$ & $2136,15 \pm 50,15$ & $2164,55 \pm 38,55$ & $\mathrm{~ns}$ \\
$12-18$ & $2581,45 \pm 75,92$ & $2581,20 \pm 64,25$ & $2622,80 \pm 45,46$ & $\mathrm{~ns}$ \\
\hline
\end{tabular}

Keterangan : P1 = ayam Ketarras warna bulu gelap, $\mathrm{P} 2=$ ayam Ketarras warna bulu putih blurik,

$\mathrm{P} 3=$ ayam Ketarras warna bulu putih, $\mathrm{ns}=$ berbeda tidak nyata $(\mathrm{P}>0,05)$.

Hasil analisis ragam menunjukkan bahwa perbedaan warna bulu pada ayam Ketarras berpengaruh tidak nyata $(\mathrm{P}>0,05)$ terhadap konsumsi ransum. Hal ini menunjukkan bahwa perbedaan warna bulu tidak mempengaruhi kosumsi ransum secara nyata. Konsumsi ransum kumulatif ayam Ketarras umur 12 - 18 minggu pada P1 (2581,45 g), P2 (2581,20 g) dan P3 (2622,80 g). Rataan konsumsi ransum ayam Ketarras pada penelitian ini berkisar 2581,20 2622,80 g. Ahmad (2017) melaporkan konsumsi ransum ayam Ketarras umur 12-18 minggu adalah 2546,36 g.

Bila dibandingkan dengan hasil penelitian Ahmad (2017), konsumsi ransum ayam Ketarras pada penelitian ini lebih tinggi $(34,84-76,44) \quad$ g. Terdapatnya perbedaan konsumsi ransum ayam Ketarras penelitian ini dengan penelitian Ahmad (2017) diduga disebabkan oleh perbedaan waktu penelitian, sehingga lingkungan berbeda. Dari hasil rataan tersebut bahwa sifat kualitatif pembedaan warna bulu tidak mempengaruhi konsumsi ransum. Menurut Rasyaf (2011) ayam petelur tipe ringan mengkonsumsi ransum lebih sedikit dibandingkan dengan ayam petelur tipe medium (ayam Ras petelur cokelat). Ayam Ketarras yang merupakan hasil dari keturunan ayam Arras dan ayam Arab karena ayam Arab termasuk tipe ayam petelur ringan tentu konsumsi ransum ayam Ketarras lebih rendah dibandingkan ayam Arras karena ayam Ketarras memiliki genetik darah yam Ras $25 \%$ dan Arab $75 \%$.

\section{Berat Badan}

Rataan berat badan mingguan ayam Ketarras umur 12 - 18 minggu disajikann pada Tabel 6.

Tabel 6. Rataan berat badan ayam Ketarras

\begin{tabular}{|c|c|c|c|c|}
\hline \multirow{2}{*}{$\begin{array}{c}\text { Umur } \\
(\text { minggu })\end{array}$} & \multicolumn{3}{|c|}{ Berat Badan } & \multirow{2}{*}{ Keterangan } \\
\hline & $\mathrm{P} 1$ & $\mathrm{P} 2$ & P3 & \\
\hline & & ....gram/ekor......... & 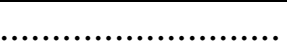 & \\
\hline 12 & $644,10 \pm 96,56$ & $603,65 \pm 139,45$ & $584,90 \pm 114,15$ & ns \\
\hline 13 & $705,20 \pm 93,78$ & $663,35 \pm 121,45$ & $647,10 \pm 125,26$ & ns \\
\hline 14 & $756,05 \pm 92,70$ & $705,30 \pm 115,40$ & $699,40 \pm 124,85$ & ns \\
\hline 15 & $800,35 \pm 89,55$ & $750,35 \pm 122,98$ & $753,05 \pm 133,39$ & ns \\
\hline 16 & $852,25 \pm 93,98$ & $810,05 \pm 117,60$ & $806,80 \pm 122,47$ & ns \\
\hline 17 & $896,10 \pm 87,92$ & $857,60 \pm 105,53$ & $856,15 \pm 134,50$ & ns \\
\hline 18 & $940,85 \pm 101,37$ & $908,95 \pm 104,46$ & $901,95 \pm 143,59$ & ns \\
\hline
\end{tabular}

Keterangan : P1 = ayam Ketarras warna bulu gelap, P2 = ayam Ketarras warna bulu putih blurik, $\mathrm{P} 3=$ ayam Ketarras warna bulu putih, $\mathrm{ns}=$ berbeda tidak nyata $(\mathrm{P}>0,05)$. 
Hasil analisis ragam menunjukkan bahwa perbedaan warna bulu berpengaruh tidak nyata $(\mathrm{P}>0,05)$ terhadap berat badan mingguan. Capaian berat badan umur 18 minggu P1 (940,85 g), P2 (908,95 g) dan P3 $(901,95 \mathrm{~g})$ berbeda tidak nyata. Tidak terdapatnya perbedaan yang nyata capaian berat badan ini disebabkan karena konsumsi ransum kumulatif selama 12 - 18 minggu berbeda tidak nyata (Tabel 5). Grafik berat badan ayam Ketarras umur 12 - 18 Minggu disajikan pada Gambar 1.

Gambar 1. memperlihatkan bahwa berat badan ayam setiap minggu meningkat dengan bertambahnya umur ayam hingga mencapai 18 minggu. Wahju (2004) menyatakan bahwa berat badan akan mengalami kenaikan dengan bertambahnya umur ayam serta mengalami perubahan komponen-komponen tubuh seperti otot, tulang dan lemak. Sistem reproduksi ayam pada periode grower mulai tumbuh dan sistem hormon reproduksi mulai berkembang dengan baik, berkaitan dengan berkembangnya sistem reproduksi maka faktor ransum harus diperhatikan, karena kegagalan dalam menyusun ransum akan berakibat fatal terhadap produksi pada masa bertelur (Rasyaf, 2008).

\section{Pertambahan berat badan}

Rataan pertambahan berat badan kumulatif ayam Ketarras umur $12-18$ minggu disajikan pada Tabel 7.

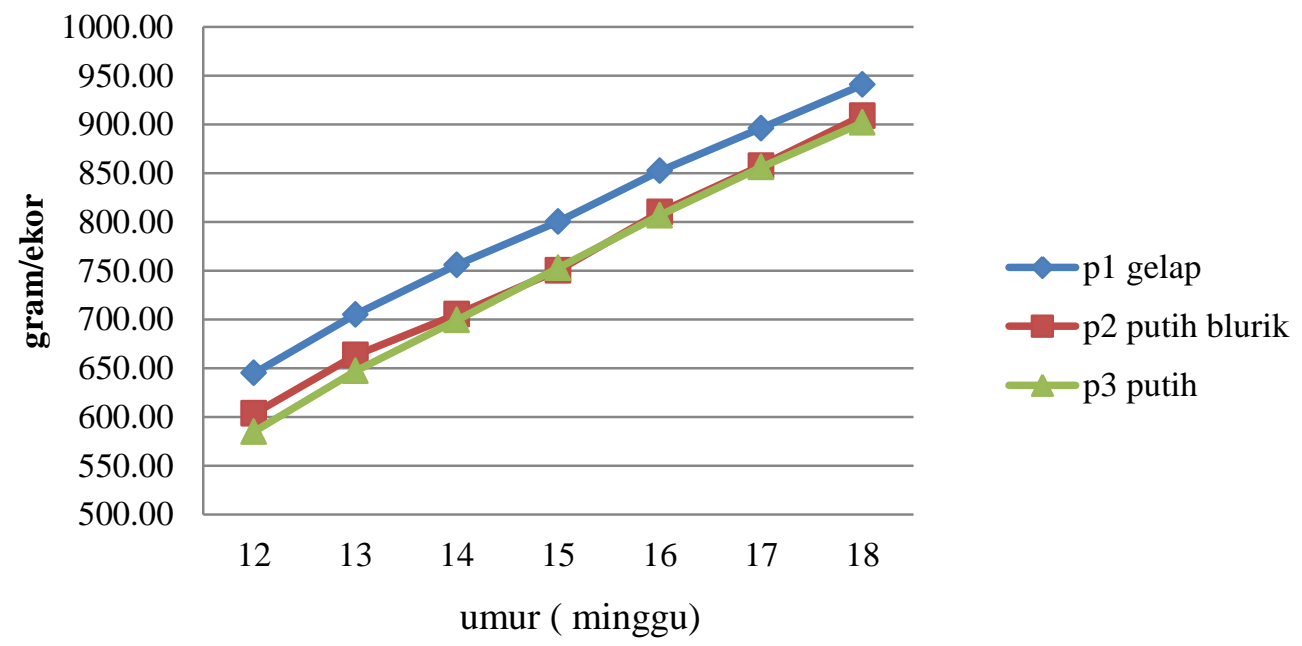

Gambar 1. Grafik berat badan ayam Ketarras umur 12-18 minggu

Tabel 7. Rataan pertambahan berat badan kumulatif ayam Ketarras

\begin{tabular}{ccccc}
\hline \multirow{2}{*}{$\begin{array}{c}\text { Umur } \\
\text { minggu })\end{array}$} & \multicolumn{3}{c}{ Pertambahan Berat Badan } & \multirow{2}{*}{ Keterangan } \\
\cline { 2 - 4 } & P1 & P2 & P3 & \\
\cline { 2 - 4 } $12-13$ & ------------------- gram/ekor--------------------- & \\
$12-14$ & $111,95 \pm 56,10 \pm 34,48$ & $59,70 \pm 38,96$ & $62,20 \pm 39,53$ & $\mathrm{~ns}$ \\
$12-15$ & $156,25 \pm 58,77$ & $101,65 \pm 44,16$ & $113,15 \pm 50,82$ & $\mathrm{~ns}$ \\
$12-16$ & $208,15 \pm 59,76$ & $206,40 \pm 51,05$ & $220,55 \pm 76,75$ & $\mathrm{~ns}$ \\
$12-17$ & $252,00 \pm 61,68$ & $253,95 \pm 60,57$ & $269,90 \pm 97,03$ & $\mathrm{~ns}$ \\
$12-18$ & $296,75 \pm 72,37$ & $305,30 \pm 78,19$ & $315,70 \pm 102,65$ & $\mathrm{~ns}$ \\
\hline
\end{tabular}

Keterangan : P1 = ayam Ketarras warna bulu gelap, $\mathrm{P} 2=$ ayam Ketarras warna bulu putih blurik,

$\mathrm{P} 3=$ ayam Ketarras warna bulu putih, $\mathrm{ns}=$ berbeda tidak nyata $(\mathrm{P}>0,05)$. 
Hasil analisis ragam menunjukkan bahwa pertambahan berat badan ketiga pola warna bulu berbeda tidak nyata $(\mathrm{P}>0,05)$. Capaian pertambahan berat badan kumulatif umur 12 sampai 18 minggu P1 (296,75 g), P2(305,30 g) dan P3(315,70 g) berbeda tidak nyata. Hal ini menunjukkan bahwa sifat kualitatif warna bulu tidak mempengaruhi pertambahan berat badan dan konsumsi secara nyata. Ahmad (2017) melaporkan capain pertambahan berat badan kumulatif ayam Ketarras selama umur 12-18 minggu adalah 430,16 g/ekor. Capaian pertambahan berat badan yang lebih rendah dengan konsumsi ransum lebih bila dibandingkan dengan penelitian Ahmad (2017) ini diduga disebabkan oleh perbedaan waktu penelitian sehingga suhu maupun cuaca berbeda. Tabara (2012) menyatakan bahwa panas yang ekstrim atau dingin akan mempengaruhi penampilan unggas dengan mengurangi pertambahan bobot badan juga meningkatkan kematian dan peka terhadap penyakit. Perubahan yang terjadi secara fisiologis sebagai akibat dari suhu lingkungan yang tinggi adalah fungsi hormon tinggi yang pada akhirnya akan mempengaruhi metabolisme.

\section{Konversi Ransum}

Rataan konversi ransum kumuatif ayam Ketarras umur 12-18 minggu disajikan pada Tabel 8 .

Tabel 8. Rataan konversi ransum kumulatif ayam Ketarras

\begin{tabular}{ccccc}
\hline \multirow{2}{*}{ Umur (minggu) } & \multicolumn{3}{c}{ Konversi Ransum } & \multirow{2}{*}{ Keterangan } \\
\cline { 2 - 4 } & $\mathrm{P} 1$ & $\mathrm{P} 2$ & $\mathrm{P} 3$ & \\
\cline { 2 - 4 } $12-13$ & $6,72 \pm 6,15$ & $6,85 \pm 5,00$ & $6,63 \pm 8,90$ & $\mathrm{~ns}$ \\
$12-14$ & $7,50 \pm 4,72$ & $8,20 \pm 4,37$ & $7,46 \pm 5,04$ & $\mathrm{~ns}$ \\
$12-15$ & $8,14 \pm 3,24$ & $8,63 \pm 3,31$ & $7,66 \pm 2,91$ & $\mathrm{~ns}$ \\
$12-16$ & $8,24 \pm 2,63$ & $8,23 \pm 2,08$ & $7,82 \pm 3,00$ & $\mathrm{~ns}$ \\
$12-17$ & $8,53 \pm 2,32$ & $8,41 \pm 1,88$ & $8,02 \pm 2,85$ & $\mathrm{~ns}$ \\
$12-18$ & $8,70 \pm 2,86$ & $8,45 \pm 2,05$ & $9,31 \pm 2,71$ & $\mathrm{~ns}$ \\
\hline
\end{tabular}

Keterangan : P1 = ayam Ketarras warna bulu gelap, $\mathrm{P} 2=$ ayam Ketarras warna bulu putih blurik,

$\mathrm{P} 3=$ ayam Ketarras warna bulu putih, $\mathrm{ns}=$ berbeda tidak nyata $(\mathrm{P}>0,05)$.

Hasil analisis ragam menunjukkan bahwa konversi ransum kumulatif ayam Ketarras umur 12-18 minggu berbeda tidak nyata $(\mathrm{P}>0,05)$. Konversi ransum kumulatif ayam Ketarras umur 12-18 minggu berturut - turut $\mathrm{P} 1(8,70), \mathrm{P} 2$ (8,45), dan P3(9,31). Ahmad (2017) melaporkan bahwa konversi ransum kumulatif ayam Ketarras umur 12-18 minggu adalah 5,97. Hal ini menunjukkan bahwa konversi ransum kumulatif penelitian Ahmad (2017) lebih rendah dibandingkan penelitian ini. Ambarwati (2016) melaporkan bahwa konversi ransum kumulatif ayam Arras umur 12-18 minggu adalah 6,30 dan ayam Arab 7,18 hal ini menunjukkan konversi ransum kumulatif ayam Ketarras penelitian ini mempunyai nilai yang lebih besar dengan kisaran 8,45-9,31. Tingginya nilai konversi ransum kumulatif pada penelitian ini disebabkan karena genetik ayam Ketarras, dengan komposisi genetik $75 \%$ ayam Arab dan 25\% ayam Ras.

\section{Umur Dewasa Kelamin, Berat Dewasa Kelamin dan Berat Telur Pertama}

Rataan umur dewasa kelamin, berat dewasa kelamin dan berat telur pertama ayam Ketarras disajikan pada Tabel 9. 
Tabel 9. Umur dewasa kelamin, berat dewasa kelamin dan berat telur pertama ayam Ketarras

\begin{tabular}{cccc}
\hline Perlakuan & Umur Dewasa Kelamin & $\begin{array}{c}\text { Berat Dewasa Kelamin } \\
(\text { gram })\end{array}$ & $\begin{array}{c}\text { Berat Telur } \\
\text { Pertama } \\
\text { (gram) }\end{array}$ \\
\hline P1 & 145 hari (20 minggu, 5 hari) & 1035 & 32 \\
P2 & 142 hari (20 minggu, 2 hari) & 992 & 31 \\
P3 & 148 hari (21 minggu, 1 hari) & 1015 & 31 \\
\hline Keterangan & $\mathrm{ns}$ & $\mathrm{ns}$ & $\mathrm{ns}$ \\
\hline
\end{tabular}

Keterangan : P1 = ayam Ketarras warna bulu gelap, P2 = ayam Ketarras warna bulu putih blurik, $\mathrm{P} 3$ = ayam Ketarras warna bulu putih, $\mathrm{ns}=$ berbeda tidak nyata $(\mathrm{P}>0,05)$.

Hasil analisis ragam menunjukkan bahwa perbedaan warna bulu berpengaruh tidak nyata $(\mathrm{P}>0,05)$ terhadap umur dewasa kelamin, berat dewasa kelamin dan berat telur pertama ayam Ketarras. Rataan umur dewasa kelamin P1 (145 hari), P2 (142 hari) dan P3 (148 hari). Hal ini menunjukkan umur dewasa kelamin ayam Ketarras berkisar 142-148 hari. Ahmad (2017) melaporkan rataan umur dewasa kelamin ayam Ketarras 128 hari, yang berarti capaian umur dewasa kelamin pada penelitian ini lebih lambat dibandingkan hasil penelitian Ahmad (2017). Hasil penelitian menunjukkan umur dewasa kelamin ayam Arras 122 hari (Ambarwati, 2016). Indra et al. (2013) menyatakan bahwa umur dewasa kelamin dipengaruhi strain, umur pertama bertelur, temperatur lingkungan, ukuran pullet, intensitas bertelur dan zat makanan dalam pakan.

Berat dewasa kelamin diperoleh berdasarkan hasil penimbangan ayam pada saat pertama kali bertelur. Hasil analisis ragam menunjukkan bahwa perbedaan warna bulu berpengaruh tidak nyata terhadap berat dewasa kelamin $(\mathrm{P}>0,05)$. Penelitian ini menunjukkan bahwa rataan berat dewasa kelamin P1 (1035 g), P2 (992 g) dan P3 (1015 g) berbeda tidak nyata. Capaian berat dewasa kelamin ayam Ketarras penelitian ini lebih ringan dibanding berat dewasa kelamin ayam Ketarras dari hasil penelitian Ahmad (2017) $1265 \mathrm{~g}$.

Hasil analisis ragam berat telur pertama menghasilkan berbeda tidak nyata $(\mathrm{P}>0,05)$. Rataan berat telur P1 (32 g), P2 (31 g) dan P3 (31 g). Capaian berat telur pertama ayam Ketarras penelitian ini tidak berbeda jauh dengan ayam Ketarras penelitian Ahmad (2017) yang menunjukkan rataan berat telur pertama 33,5 g. Lebih kecilnya berat telur pertama ayam Ketarras pada penelitian ini desebabkan karena faktor ukuran pullet, berat badan ayam Ketarras pada saat dewasa kelamin pada penelitian berkisar 992-1035 g sedangkan penelitian Ahmad (2017) 1265 g. semakin besar ukuran pullet maka semakin besar ukuran berat telur dan semakin kecil ukuran pullet maka semakin kecil ukuran berat telur. Indra et al. (2013) menyatakan bahwa berat telur dipengaruhi oleh strain, temperatur lingkungan, ukuran pullet.

\section{KESIMPULAN}

Perbedaan sifat kualitatif (pola warna bulu) tidak mempengaruhi performans ayam Ketarras umur 12 sampai dewasa kelamin. Perlu dilanjutkan penelitian ini untuk mengevaluasi produksi telur ayam Ketarras berdasarkan pola warna bulu.

\section{DAFTAR PUSTAKA}

Ahmad, K. 2016 Performans ayam Ketarras betina umur 12 minggu - dewasa kelamin. Skripsi. Jurusan Peternakan Fakultas Pertanian Universitas Bengkulu.

Ambarwati, N. 2016. Performans keturunan ayam Arab dengan ayam Ras petelur (ayam Arras) betina dan ayam Arab betina umur 12 minggu - dewasa kelamin. Skripsi. Jurusan Peternakan 
Fakultas Pertanian Universitas Bengkulu.

Anggriawan, N. 2016. Performans keturunan ayam Arab dengan ayam Ras petelur (ayam Arras) betina umur 2-12 minggu. Skripsi. Jurusan Peternakan Fakultas Pertanian Universitas Bengkulu.

Fadilah. 2004. Aneka Penyakit pada Ayam dan Cara Mengatasinya. PT. Agromedia Pustaka. Jakarta.

Hartadi. H. S., Reksohardiprojo dan AD. Tilman. 2005. Tabel Komposisi Pakan Untuk Indonesia. Cetakan ke IV. Universitas Gajah Mada.

Hidayatullah, M. A. 2016. Performans ayam Ketarras pada umur 2-12 minggu berdasarkan pola warna bulu. Skripsi. Jurusan Peternakan Fakultas Pertanian Universitas Bengkulu.

Indra, G. K Achmanu, dan A. Nurgiartiningsih. 2013. Performans produksi Ayam Arab (Gallus turcicus) berdasarkan warna bulu. Jurnal Ternak Tropika, 14 (1):8-14

Marliya, O. 2017 Uji kualitas fisik dan akseptabilitas telur ayam Ketarras sebagai telur ayam Kampung. Skripsi. Jurusan Peternakan Fakultas Pertanian Universitas Bengkulu.
National Research Council. 1994. Nutrient Requirement of Poultry. Ninth Resived Edition. Printing and Publishing National Academiy of Science. Washington.

PT.Japfa Comfeed, 2001, Ayam Petelur. Https://www,japfacomfeed.co.id. Diakses pada tanggal 26 April 2018.

Rasyaf, M. 2008. Beternak Ayam Petelur. Penebar Swadaya. Jakarta.

Rasyaf, M. 2011. Panduan Beternak Ayam Pedaging. Penebar swadaya. Jakarta.

Saputra, M. A. 2018. Performans ayam Ketarras mulai dewasa kelamin sampai umur 28 Minggu. Sripsi. Jurusan Peternakan. Fakultas Pertanian. Universitas Bengkulu.

Surnoto, A. A. D. 2018. Performans produksi telur ayam Ketarras dan ayam Arab mulai umur 28-40 Minggu . Skripsi. Jurusan Peternakan. Fakultas Pertanian. Universitas Bengkulu.

Tabara, J. H. 2012. Respon ayam ras pedaging pada lokasi pemeliharaan daerah pantai dan pegunungan. Fakultas Peternakan. Universitas Hasanuddin. Makasar

Wahju, J. 2004. Ilmu Nutrisi Unggas. Cetakan ke 5. Gadjah Mada University press. Yogyakarta. 